\title{
Trends in Triglyceride (Fat) Levels of Various Stages of Pregnancy in Nigerian Women
}

\author{
Affi Ayuba1 ${ }^{*}$, Josiah Mutihir'1, Dalili Shabbal'2, A. S. Longwan'1, T. S. Selowo', A. Lukden', \\ Stephen Pam1, Mercy Solomon' ${ }^{1}$
}

${ }^{1}$ Department Obstetric and Gynaecologist, Jos University Teaching Hospital, Jos, Nigeria

${ }^{2}$ Department of Chemical Pathology, University of Abuja, Abuja, Nigeria

Email: ^ayubaaffi67@gmail.com, turimutihir@gmail.com, dalilishabbal@yahoo.com, longwan@yahoo.com,

selowomd@gmail.com,mlukden@gmail.com, stephenpamo@yahoo.com, mercygunat@gmail.com

How to cite this paper: Ayuba, A., Mutihir, J., Shabbal, D., Longwan, A.S., Selowo, T.S., Lukden, A., Pam, S. and Solomon, M. (2018) Trends in Triglyceride (Fat) Levels of Various Stages of Pregnancy in Nigerian Women. Open Journal of Obstetrics and Gynecology, 8, 1247-1254.

https://doi.org/10.4236/ojog.2018.812126

Received: August 7, 2018

Accepted: October 26, 2018

Published: October 29, 2018

Copyright $\odot 2018$ by authors and Scientific Research Publishing Inc. This work is licensed under the Creative Commons Attribution International License (CC BY 4.0).

http://creativecommons.org/licenses/by/4.0/

\begin{abstract}
Background: In developing countries like Nigeria, with poor socio-economic, early marriage, poor acceptance of contraception, poor spacing of pregnancies, high fertility rate and poor maternal and child health indices, leading to poor maternal-child outcome. There is a need to investigate the pattern of serum lipid changes during pregnancy in Nigeria women as hyperlipidemia may lead to poor maternal outcome. Materials and methods: A total of one hundred and forty (140) subjects between the ages of 20 and 45 years with mean age $29.74 \pm 6.5$ years of the study population. Group 1: the control comprises of thirty-five (35) healthy non pregnant subjects with mean age of $26.84 \pm 5.2$ volunteers of Nigeria origin. Group 2: the test involved one hundred and five (105) apparently healthy pregnant Nigerian women sub-divided into three groups; $X, Y$ and $Z$ each made of thirty-five (35) subjects distributed into $1^{\text {st }}, 2^{\text {nd }}$ and $3^{\text {rd }}$ trimester of pregnancy respectively. The TG assay was analyzed using enzymatic spectrophotometric method as described by Biosystems. Results: The result analysis showed a significant increase ( $\mathrm{p} \leq$ 0.05 ) in the TG level during the first trimester of pregnancy when compared with control as shown in Table 1 . There was a significant increase $(\mathrm{p} \leq 0.05)$ in the TG levels during the second trimester of pregnancy when compared with that of the control subjects. During the third trimester of pregnancy there was a significant increase in TG levels when compared with the control subjects. Conclusion: This work revealed that the most dramatic change in the lipid profile in normal pregnancy is serum hypertriglyceridemia, which may be as high as two-three folds in the third trimester over the levels in non pregnant subjects. The estimation of lipid profile is strongly recommended as part of the laboratory investigations during pregnancy. Since studies in recent past have incriminated abnormal lipid metabolism during pregnancy in the
\end{abstract}


pathogenesis of atherosclerotic, ischemia heart disease, intrauterine growth disease, intrauterine growth retardation and hypertension.

\section{Keywords}

Gestational Age, Maternal Age, Parity, Gravidity, Trimester

\section{Introduction}

During pregnancy, there are physiological changes in TG metabolism which may be related to increased metabolic rate [1] [2] [3].

There is accumulation of fat during early pregnancy due to hyperphagia and increased lipogenesis. It has been noted that in normal pregnancy, TG is elevated with increasing gestational age. It was suggested that increased progesterone in mid gestation acts as lipostat in the hypothalamus [4] [5]. It has been observed that the increase in the maternal lipid profile in the third trimester is in response to the maternal switch from carbohydrate to fat metabolism which is an alternative pathway for energy generation due to high energy demand.

However, in complicated pregnancy there is a possible defect in the mechanism of adjusting physiological hyperlipidemia. Plasma TG in $1^{\text {st }}$ trimester of pregnancy may predict the incidence of severe preeclampsia [6] [7].

A study in port-Harcourt showed that pregnancy in black Nigerian women is associated with hyperlipidemia [8]. The study determined the changes in the TG levels of women at various stages of pregnancy.

The serum lipid of 269 pregnant women in North Eastern Borno was studied. Thirty four apparently healthy non pregnant women were used as controls. There was hyperlipidemia in these subjects [9].

In Israel, a done study showed that TG level doubled in $3^{\text {rd }}$ trimester [10] [11] [12]. However it was also demonstrated that there was an initial decrease in TG level in $1^{\text {st }}$ trimester a pattern not shown in previous studies. In these studies consecutive pregnancies do not influence baseline (non-pregnant) TG levels.

This study examines the extent of changes in TG levels at various stages of gestation which may indicate a risk factor for atherogenicity.

\section{Patients and Methods}

\subsection{Study Design and Settings}

This is a prospective interventional study done between the months of august and October 2008 at the ante-natal clinic (ANC) of Jos University Hospital, Jos Plateau state, North-Central Nigeria.

\subsection{Sample and Sampling Technique}

A total of one hundred and forty subjects were recruited by random sampling techniques. Sample size was approximated from the calculated sample size be- 
low.

$$
N=\frac{Z^{2} P Q}{d^{2}}
$$

where $N=$ Sample Size, $P=$ Prevalence of $1 \%$ was assumed; $d=$ Permissible error of 5\% (0.05) or degree of accuracy; $Q=1-P ; Z=1.96$ (Confidence Interval)

$$
N=\frac{(1.96)^{2} \times(0.1) \times(1-0.1)}{0.0025}=153.63
$$

They were between the ages of 18 to 45 years with mean of $29.74 \pm 6.5$ years of the study population. Group 1; the control comprises of thirty-five (35) healthy non pregnant volunteers of Nigeria origin with mean age of $26.84 \pm 5.2$. Group 2; test involved one hundred and five apparently healthy pregnant Nigerian women attending ante-natal clinic at JUTH, Jos between March 2008 and December 2008.

All subjects were advised to have an overnight fast. $5 \mathrm{mls}$ venous blood was collected from the antecubital vein under aseptic precaution from each subject into the plain bottles. Serum was separated by centrifugation at $4000 \mathrm{rpm}$ for 5 minutes at $36^{\circ} \mathrm{C}$ and stored at $-20^{\circ} \mathrm{C}$ till estimation.

\subsection{Data Analysis}

The stored serum sample was thawed and TG was assayed using a three step enzymatic method. The values of TG concentration in $\mathrm{mmol} / \mathrm{L}$ were determined by reading off the concentration from the absorbance from a standard curve. The NCEP adult treatment panel has identified borderline high TG as levels of (1.7 $2.3 \mathrm{mmol} / \mathrm{L}$ ) and very high as $5.6 \mathrm{mmol} / \mathrm{L}$.

\section{1) Ethics}

The study was conducted in compliance with the declaration on the right of the patient after the approval by the ethical committee of JUTH, Jos. Also an informed consent was obtained from all subjects enrolled for the study.

Inclusion Criteria: consented pregnant women with uncomplicated pregnancy were included in the study.

Exclusion Criteria: Patient with hypertension, diabetes, heart disease as well as those unwilling to participate.

\section{2) Statistics}

All measured variables for the study groups were presented as mean, standard deviation and was used to compare between different groups. All data was analyzed.

Student t-test was used for comparison of means and $\mathrm{P}<0.05$ was considered to be statistically significant.

\section{Results}

A total of one hundred and forty subjects were recruited by random sampling techniques. They were between the ages of 18 to 45 years with mean of $29.74 \pm$ 
6.5 years of the study population. Group 1; the control comprises of thirty-five (35) healthy non pregnant volunteers of Nigeria origin with mean age of $26.84 \pm$ 5.2. Group 2; test involved one hundred and five apparently healthy pregnant Nigerian women attending ante-natal clinic at JUTH, Jos.

A mean SD of TG in pregnant women were 1.78, 2.80, $3.84 \mathrm{mmol} / \mathrm{L}$ respectively and for control 1.68, 1.08 and $1.68 \mathrm{mmol} / \mathrm{L}$ respectively.

The result analysis shows a significant increase $(p \leq 0.05)$ in the TG level during the first trimester of pregnancy when compared with control as shown in Table 1.

There was a significant increase $(\mathrm{p} \leq 0.05)$ in the TG levels during the second trimester of pregnancy when compared with that of the control subjects (Table 2).

The result shows a significant increase $(\mathrm{p}<0.05)$ in the TG, levels during the third trimester of pregnancy when compared with the control subjects (Table 3).

\section{Discussion}

Studies revealed that the most dramatic damage in the lipid profile in normal pregnancy is serum hypertriglyceridemia, which may be as high as two three folds in the third trimester over the levels in non pregnant women [13]. In this study, this observation holds true. Here it was observed that the concentration of serum triglyceride in normal pregnancy increased with increasing gestational age and the serum triglyceride concentration showing a very significant increase in the third trimester of normal pregnancy than in the non pregnant women, the mean value being raised almost two folds. The principal modulator of this hypertriglyceridemia is estrogen as pregnancy is associated with hyperestrogenemia. Estrogen induces hepatic biosynthesis of endogenous triglycerides, which is carried by VLDL (12).

Table 1. TG level (Mean \pm S.D in $\mathrm{mmol} / \mathrm{L}$ ) of pregnant women in the first trimester and normal control. $\mathrm{t}$-Test comparing $1^{\text {st }}$ stage and normal, (a) Group Statistics; (b) Independent Samples Test.

(a)

\begin{tabular}{ccccc}
\hline Stages & N & Mean & Std Deviation & Std. Error Mean \\
\hline $1^{\text {st }}$ Stage & 35 & 1.7834 & 0.79898 & 0.13505 \\
Control & 35 & 1.6810 & 0.63083 & 0.10663 \\
\hline
\end{tabular}

(b)

\begin{tabular}{|c|c|c|c|c|c|c|c|c|c|c|}
\hline & & $\begin{array}{l}\text { Levene's test } \\
\text { for Equality of }\end{array}$ & & & & T-Test & or equality o & Means & & \\
\hline & & F & Sig & $\mathrm{T}$ & Df & $\begin{array}{c}\text { Sig. } \\
\text { (2-tailed) }\end{array}$ & $\begin{array}{c}\text { Mean } \\
\text { Difference }\end{array}$ & $\begin{array}{l}\text { Std. Error } \\
\text { Difference }\end{array}$ & $\begin{array}{r}95 \% \text { Conf } \\
\text { of the }\end{array}$ & $\begin{array}{l}\text { ce interva } \\
\text { erence }\end{array}$ \\
\hline \multirow[t]{2}{*}{ Conc. } & $\begin{array}{c}\text { Equal } \\
\text { Variance }\end{array}$ & 0.013 & 0.91 & 0.455 & 68 & 0.651 & 0.07829 & 0.17207 & -0.2651 & 0.42165 \\
\hline & $\begin{array}{c}\text { Equal } \\
\text { Variance not }\end{array}$ & & & 0.455 & 64.527 & 0.651 & 0.07829 & 0.17207 & 0.2654 & 0.42199 \\
\hline
\end{tabular}


Table 2. TG LEVEL (Mean \pm S.D in $\mathrm{mmol} / \mathrm{L}$ ) of pregnant women in their second trimester and normal control as compared with second trimester. $t$-Test comparing $2^{\text {nd }}$ stage and normal, (a) Group statistics; (b) Independent Samples Test.

(a)

\begin{tabular}{cccccc}
\hline & Stages & $\mathbf{N}$ & Mean & Std Deviation & Std. Error Mean \\
\hline Conc. & $2^{\text {nd }}$ Stage & 35 & 2.8031 & 0.94121 & 0.15909 \\
& Control & 35 & 1.0810 & 0.63083 & 0.10663 \\
\hline
\end{tabular}

(b)

\begin{tabular}{|c|c|c|c|c|c|c|c|c|c|c|}
\hline & & $\begin{array}{l}\text { Levene's test } \\
\text { for Equality }\end{array}$ & & & & T-Test $\mathrm{f}$ & r equality of & leans & & \\
\hline & & F & Sig & $\mathrm{T}$ & Df & $\begin{array}{c}\text { Sig. } \\
(2 \text {-tailed })\end{array}$ & $\begin{array}{c}\text { Mean } \\
\text { Difference }\end{array}$ & $\begin{array}{l}\text { Std. Error } \\
\text { Difference }\end{array}$ & $\begin{array}{r}95 \% \text { Conf } \\
\text { of the }\end{array}$ & $\begin{array}{l}\text { ce interval } \\
\text { erence }\end{array}$ \\
\hline \multirow[t]{2}{*}{ Conc. } & $\begin{array}{c}\text { Equal } \\
\text { Variance }\end{array}$ & 5.805 & 0.019 & 5.733 & 68 & 0 & 1.098 & 0.19152 & 0.7158 & 1.48118 \\
\hline & $\begin{array}{c}\text { Equal } \\
\text { Variance not }\end{array}$ & & & 5.733 & 49.417 & 0 & 0.098 & 0.19158 & 0.7158 & 1.48118 \\
\hline
\end{tabular}

Table 3. TG LEVEL (Mean \pm S.D in $\mathrm{mmol} / \mathrm{L}$ ) of pregnant women in their third trimester and normal control as compared with second trimester. T-Test comparing $3^{\text {rd }}$ stage and normal, (a) Group statistics; (b) Independent Samples Tests.

(a)

\begin{tabular}{cccccc}
\hline & Stages & N & Mean & Std Deviation & Std. Error Mean \\
\hline Conc. & $3^{\text {rd }}$ Stage & 35 & 3.8483 & 0.49845 & 0.08425 \\
& Normal Stage & 35 & 1.6810 & 0.63083 & 0.10663 \\
\hline
\end{tabular}

(b)

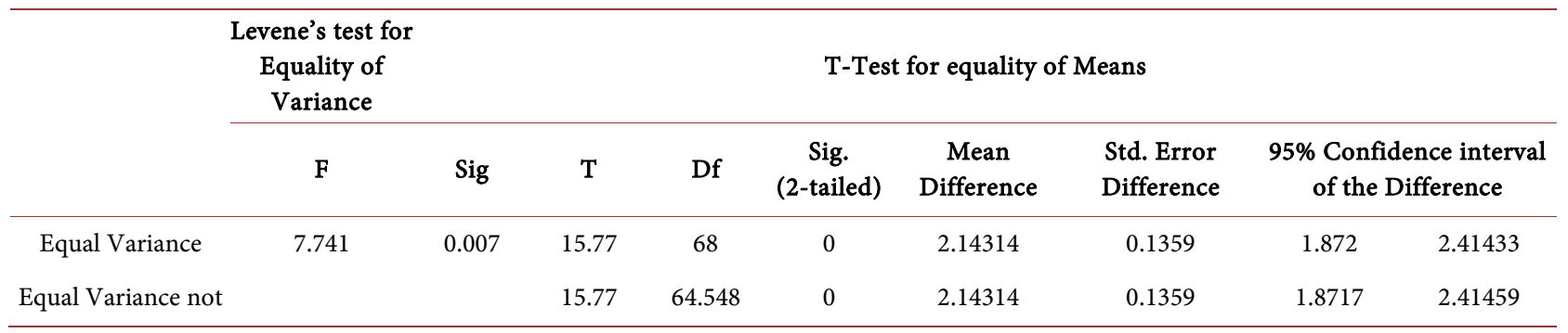

Furthermore, this study showed that triglyceride levels of the test subjects in the first trimester were higher than that of the control subjects. This is in agreement with those of Klovich and Hallman [14], in which they observed that in the first trimester of pregnancy there is formation of Zygote in the uterine wall this accounts for the elevated levels of triglyceride in the first trimester [15]. Total triglyceride of the test subjects in the second trimester was observed to be higher than those of the control subjects. This is in line with the findings of wald and Guckle [9], who observed that the increase in the maternal lipid profile is in response to the maternal switch from carbohydrate of fat metabolism which is an alternative pathway for energy generation due to high energy demand. Total triglyceride, of the test subjects in the third trimester was higher than those of the control subjects. This is in line with results of Russed and cooper [16], in 
which they reported that there is development of foetal organ in the Third Trimester.

This is in agreement with Munoz et al. [17], who reported that total Triglyceride increased progressively throughout pregnancy with significantly higher values after $25^{\text {th }}$ week of gestation. This study also showed significant increase $(\mathrm{p}<$ 0.05 ) in triglyceride, levels during the third trimester when compared with the first trimester of pregnancy. This agrees with the study conducted by Desoye et al. [18] [19] [20]. In which they observed that LDL levels peaked at approximately week 36 .

Two consistent manifestations of altered maternal lipid metabolism associated with gestation are the accumulation of lipids in maternal issues and the development of material hyperlipidaemia [3]. This is reflected in the results obtained from this research work. Studies in recent past have incriminated abnormal lipid metabolism during pregnancy in the pathogenesis of atherosclerosis ischaemic heart disease, intrauterine growth disease intrauterine growth retardation and hypertension [20] [21] [22].

\section{Conclusions and Recommendations}

Lipid profile result showed that TG was significantly lower in the control group than in pregnant women. These changes may be due to the change in metabolism of the pregnant women as well as diet during and after pregnancy.

The highest TG level in the first trimester was clearly more than the control. The increased blood TG level was due to delayed TG clearance and when there is concurrent high blood pressure, pre-eclampsia may ensue.

This study illuminates and brings to understanding the possible mechanism of developing pre-eclampsia.

Lipid profile can be recommended as part of routine antenatal tests and if possible adopted by the clinical services department of this institution.

This may reduce or even eliminate complications of hyperlipidemia in pregnancy.

\section{Conflicts of Interest}

The authors declare no conflicts of interest regarding the publication of this paper.

\section{References}

[1] Stock, M.J. and Metealfe, J. (1994) Maternal Physiology during Gestation. In: Knobil, E. and Neil, J.D., Eds., The Physiology of Reproduction Ravens Press, New York, 947-983.

[2] Satter, N., Greer, I.A. and Galloway, P.J. (1999) The Journal of Clinical Endocrinology and Metabolism, 84, 128-130.

[3] Jimeney, D.M., Pocovi, M. and Ramon, C.J. (1988) Longitudinal Study of Plasma Lipids and Lipoprotein Cholesterol in Normal Pregnancy and Puerperium. Gynecologic and Obstetric Investigation, 25, 158-164. https://doi.org/10.1159/000293765 
[4] Iregbu, S.C. and Iregbu, F.U.A. (2012) Review of Self Management of Diabetes in Africa. African Journal of Diabetes Medicine, 20, 16-19.

[5] Body, E.M.J. (1934) The Lipemia of Pregnancy. The Journal of Clinical Investigation, 13, 347-363. https://doi.org/10.1172/JCI100590

[6] Adebisi, S.A. and Aboyeji, P.A. (2004) Plasma Lipids and Lipoproteins during First Trimester in Pregnant Nigerian Women: Llorin Experience. Nigerian Postgraduate Medical Journal, 11, 1-3.

[7] Loke, D.F., Viegas, O.A., Kek, L.P., Rauff, M., Thai, A.C. and Ratnam, S.S. (1991) Lipid Profiles during and after Normal Pregnancy. Gynecologic and Obstetric, 32, 144-147.

[8] Ojule, A.C., Akani, C.I. and Opurum, H.C. (2005) Plasma Lipids during Pregnancy in Women in Port Harcourt, Nigeria. Nigerian Journal of Medicine, 14, 155-160.

[9] Ezeanyika, L.U.S., Kassab, K.A., Mutala, Y.S., Ynusu, I. and Ibrahim, F.O. (2002) Serum Lipid Profiles of Population of Pregnant Women in Boron State, Nigeria. Global Journal of Pure and Applied Science, 8, 315-318.

[10] Setareh, A., Mitra, M.G., Sedigheh, B., Shoaleh, S., Yousefinejad, V. and Siroos, S. (2009) Material Plasma Lipid Concentration in First Trimester of Pregnancy and Risk of Server Pre-Eclampmias. Pakistan Journal of Medical Sciences Online, 25, 505-567.

[11] Swartwout, J.R., Unglaub, W.G. and Smith, R.C. (1960) Vitamin B, Serum Lipid and Placental Arteriolar Lesions in Human Pregnancy. The American Journal of Clinical Nutrition, 8, 434-444. https://doi.org/10.1093/ajcn/8.4.434

[12] Okojie, F.O., Blessing, I.O., Eseigbe, M.A., Okhiai, O., Faith, U. and Magdalence, D. (2011) Comparative Study of Lipd Profiles of Normal Pregnant Women in the Different Trimesters. Archives of Applied Science Research, 3, 528-532.

[13] Jamil, A.A.T., Elsoni, B., Zaki, H.Y., et al. (2013) Assessment of Lipid Profile in Sudanese Pregnant Women. Journal of Biotechnology, 1, 4-15.

[14] Olatunji, L.A., Soladoye, A.O., Fawole, A.A., Jimoh, R.O. and Olatunji, V.A. (2008) Association between Plasma Triglyceride and Haemorheological Variables in Nigerian Primigravidae and Multigravidae. Journal of Research in Medical Sciences, 2, 116-120.

[15] Preeta, D., Elaina, L., Anita, K., et al. (2009) Human Cardiac Development in the 1st Trimester. Circulation, 120, 343-351.

[16] Russell, J. and Cooper, C. (1989) Clinical Chemistry, 35, 1005-1015.

[17] Glueek, C.J., Fallet, R.W. and Scheel, D. (1975) Effects of Estrogenic Components on Triglyzeride Kinetics. Metabolism, 24, 537-545.

[18] Chiang, A.N., Yang, M.L., Hung, J.H., Chon, P., Shyn, S.K. and Ng, H.T. (1995) Alterations of Serum Lipid Levels and Their Biological Relevances during and after Pregnancy. Life Sciences, 56, 2367-2375.

[19] Desoye, G., Schweditch, M.O., Preiffer, K.P., Zechner, R. and Kostner, G.M.J. (1987) Correlation of Hormones with Lipid and Lipoprotein Levels During Normal Pregnancy and Postpartum. The Journal of Clinical Endocrinology and Metabolism, 64, 704. https://doi.org/10.1210/jcem-64-4-704

[20] Brizzi, P., Tonolo, G. and Esposito, F. (1999) Lipoprotein Metabolism during Normal Pregnancy. American Journal of Obstetrics \& Gynecology, 181, 430-434. https://doi.org/10.1016/S0002-9378(99)70574-0

[21] Mankuta, D., Elami-Suzin, M., Elhayani, A. and Vinker, S. (2010) Lipid Profile in Consecutive Pregnancies. Lipids in Health and Disease, 9, 58. 
[22] Desoye, G., Schweditch, M.O., Preiffer, K.P., Zechner, R. and Kostner, G.M. (1987) Correlation of Hormones with Lipid and Lipoprotein Levels during Normal Pregnancy and Postpartum. The Journal of Clinical Endocrinology \& Metabolism, 64, 704-712. https://doi.org/10.1210/jcem-64-4-704

\section{Publication List in the Last Two Years}

1) Reference Interval of Thyroxine and thyroid stimulating hormone of healthy new born in Jos University Teaching Hosptial (Nigerian Journal of Medicine, 2007).

2) SUA threshold and blood pressure in elderly rural Panyam farmers of plateau central (International Journal of Biochemistry accepted 2008).

3) Patients satisfaction with services of chemical pathology Department of JUTH (Nigeria Journal of Medicine, 2008). 